\title{
EFEK PENGUKURAN KEUANGAN DAN NON KEUANGAN TERHADAP KINERJA: PANDANGAN TEORI PENETAPAN TUJUAN
}

\author{
Monika Palupi Murniati \\ Ranto P. Sihombing \\ Clara Susilawati \\ Dosen Fakultas Ekonomi dan Bisnis Jurusan Akuntansi Unika Soegijapranata Semarang \\ e-Mail: ika_lupi@yahoo.co.id
}

\begin{abstract}
The aim of this study tested the effects of the perception of fairness measure for assessing performance against the performance of the mediation of impact, competence and selfdetermination as an aspect of empowerment. This research uses experimental studies as a method of data collection by providing a variable size treatmen on performance measurement with the difficulty level objectives and the level of difficulty of the task. Experimental design used $2 \times 2 \times 2$ between subjects.

Results from this study showed differences in the perception of fairness subordinate to measures of performance. But the interaction between the size of the performance measurement with goal difficulty and task difficulty did not provide evidence of a significant difference in perceptions of fairness of the performance measure. The mediating effect of impact, competence and self-determination with the perception fairness subordinate to the performance provides empirical evidence that perceptions of fairness subordinate to measure performance assessment can form subordinate beliefs are described by impact, competence and self-determination and enhance the performance of subordinate.
\end{abstract}

Keywords: competence, fairness, performance measurement, self determination

\begin{abstract}
ABSTRAK
Tujuan riset ini adalah untuk menguji efek persepsi fairness ukuran penilain kinerja terhadap kinerja dengan mediasi impact, competence dan self determination sebagai aspek empowerment. Riset ini menggunakan studi eksperimen sebagai metoda pengumpulan data dengan memberikan treatment pada variabel ukuran penilaian kinerja dengan tingkat kesulitan tujuan dan tingkat kesulitan tugas. Desain eksperimen yang digunakan adalah $2 \times 2 \times 2$ antar subjek. Hasil dari riset ini menunjukkan adanya perbedaan persepsi fairness subordinat terhadap ukuran kinerja. Tetapi interaksi antara ukuran penilaian kinerja dengan kesulitan tujuan dan kesulitan tugas tidak memberikan bukti adanya perbedaan signifikan persepsi fairness terhadap ukuran penilaian kinerja. Efek mediasi impact, competence dan self determination dengan persepsi fairnessi subordinat terhadap kinerja memberikan bukti empiris bahwa persepsi fairness subordinat terhadap ukuran penilaian kinerja dapat membentuk keyakinan subordinat yang dijelaskan oleh impact, competence dan self determination dan meningkatkan kinerja subordinat.
\end{abstract}

Kata kunci: keadilan, kompetensi, pengukuran kinerja, self-determination 
Efek penggunaan ukuran kinerja terhadap perilaku subordinat telah berkembang sejak tahun 1970-an yang diawali oleh riset Hopwood (1972). Dominasi riset pengukuran kinerja menggunakan ukuran finansial untuk menjelaskan efek pengukuran kinerja terhadap beberapa variabel dependen berbeda seperti kinerja dan kepercayaan terhadap atasan. Kaplan (1984) memberikan pemikiran mengenai penggunaan ukuran non finansial dalam pengukuran kinerja yang kemudian dikenal dengan balance score card.

Fokus ukuran non finansial memungkinan pengukuran kinerja dapat dilakukan dengan memperhatikan banyak dimensi yang terlibat dalam pencapaian kinerja. Kinerja yang dicapai tidak hanya didukung oleh aktivitas finansial tetapi juga oleh interaksi dengan konsumen, individu dalam kelompok, supplier dan setiap bagian dalam suatu organisasi. Ukuran kinerja non finansial memungkinkan aktivitas dan peran yang tidak mempunyai hubungan langsung dengan pencapaian laba akan mendapatkan respek. Kaplan dan Atkinson (1998) menyatakan bahwa penggunaan ukuran non finansial menekankan pada tujuan jangka panjang. Ketika individu yang memiliki peran tidak langsung terhadap pencapaian laba, memiliki dimensi ukuran kinerja sesuai dengan perannya dalam organisasi, maka hal ini akan berdampak pada perilaku individu. Hal ini dapat dijelaskan karena ukuran yang digunakan untuk melakukan pengukuran kinerja sesuai dengan karakteristik tugas dan perannya meski tidak secara langsung berdampak pada pencapaian laba. Perilaku positif yang terbentuk ini kemudian menjadi alasan perkembangan fokus riset selanjutnya.

Lau dan Sholihin (2005) mengembangkan riset penilaian kinerja dengan memperhatikan konsekuensi perilaku individu dalam sebuah proses penilaian kinerja. Alasan fokus ini didasarkan pada konsekuensi pengukuran kinerja terhadap reward yang akan diterima. Lind dan Tyler (1988) dan Lau dan Lim (2002) menyatakan pentingnya persepsi fairness subordinat terhadap ukuran kinerja yang digunakan untuk mengukur kinerjanya. Persepsi fairness terhadap ukuran kinerja oleh subordinat disebut okeh Lind dan Tyler (1988) sebagai keadilan prosedural. Tan dan Lau (2012) menyatakan bahwa penggunaan ukuran non finansial berpengaruh signifikan terhadap persepsi fairnes subordinat. Ketika subordinat merasa bahwa ukuran yang digunakan untuk mengukur kinerjanya fair, maka motivasi untuk membuat keputusan yang memberikan benefit bagi organisasi. Penjelasan ini sejalan dengan riset-riset empowerment yang menjelaskan bagaimana diskresi yang diberikan oleh superior kepada subordinat untuk membuat keputusan dalam pekerjaan mereka melalui motivasi skema reward yang diterima dan dipersepsikan fair, dapat membentuk perilaku positif.

Goal setting theory menjelaskan bagaimana karakteristik dari tujuan yang ditetapkan bersama oleh superior dan subordinat dapat menjadi motivasi individu dalam mencapai tujuan tersebut. Tingkat kesulitan tujuan dan tugas menjadi karakteristik yang akan mempengaruhi bagaimana motivasi yang terbentuk dalam diri subordinat mampu menggerakkan pencapaian kinerja yang baik. Fisher, dkk (2003) menyatakan bahwa ada hubungan positif antara kesulitan tujuan dan kinerja. Hal ini berarti tingkat kesulitan tujuan memiliki efek motivasi bagi pencapaian tujuan. Temuan riset Kelly, dkk (2010) memberikan hasil yang konsisten bahwa ketika tingkat kesulitan tujuan tinggi sulit akan mengarah pada hasil yang positif bagi subordinat dalam mencapai kinerjanya.

Kruger (1999) menemukan bahwa individu mengestimasi kinerjanya lebih baik ketika tugas yang dilakukan lebih mudah daripada ketika tingkat kesulitan tugas tinggi. Tingkat kesulitan tugas yang berbeda akan membutuhkan kemampuan kognitif yang berbeda untuk mencapai tujuan yang ditetapkan (Chandller dan Sweller dalam Ning Ho, 2010). Hal ini berarti perbedaan tingkat kesulitan tugas yang diberikan kepada subordinat untuk mencapai tujuan yang sama tingkat kesulitannya akan mempengaruhi pencapaian kinerja yang berbeda. 
Dua karakteristik tujuan di atas memiliki efek bagaimana penetapan tujuan antara superior dan subordinat tehadap perilaku individu dalam suatu organisasi. Sementara perbedaan ukuran kinerja yang mempengaruhi persepsi fairness dan reward yang akan diterima memiliki efek terhadap perilaku individu. Ukuran kinerja merupakan bentuk motivasi eksternal bagi individu, sedangkan proses penetapan tujuan yang dijelaskan oleh goal setting theory merupakan cara untuk membentuk motivasi internal individu dalam mencapai tujuan. Kondisi ini tentu akan berpengaruh terhadap bagaimana individu akan berperilaku dalam mencapai tujuan. Hal ini dapat dijelaskan dengan empowerment yang dapat menunjukkan bagaimana individu ketika berada dalam ukuran kinerja dan karakteristik tujuan yang berbeda dengan diskresi dari superior, membuat keputusan atas pekerjaan yang menjadi tanggung jawabnya. Pemikiran ini konsisten dengan pendapat Coote, dkk (2004) bahwa perlu adanya pemahaman yang komprehensif untuk menjelaskan pada kondisi apa empowerment dapat memberikan efek positif bagi perilaku subordinat. Riset ini bertujuan untuk menguji efek ukuran kinerja terhadap terbentuknya perilaku positif melalui motivasi yang melibatkan peran subordinat yang dijelaskan oleh goal setting theory dan empowerment.

Pengukuran kinerja merupakan proses evaluasi superior terhadap kinerja yang telah dicapai oleh subodinat. Kaplan (1984) menyatakan bahwa dalam pengukuran kinerja sulit untuk menghubungkan efek aktivitas dengan profit pada periode tertentu. Hal ini mengakibatkan aktivitasaktivitas subodinat yang dilakukan saat ini dan mempunyai konsekuensi tidak langsung terhadap perolehan pendapatan saat ini sering diukur dengan dasar finansial. Berdasarkan fenomena ini, maka diusulkan ukuran kinerja non finansial yang dapat menjadi indikator yang baik untuk future profitability. Hoque, dkk (2001) menyatakan bahwa multiple measurement dapat memberikan motivasi bagi subordinat untuk melakukan perbaikan aktivitas yang mendukung pencapaian tujuan organisasi. Hal ini dapat terjadi karena aktivitas-aktivitas mereka menjadi ukuran dari kinerja mereka meski tidak secara langsung berkaitan dengan perolehan profit saat ini.

Kaplan dan Atkinson (1998) menyatakan bahwa penggunaan ukuran finansial dan non finansial dalam mengukur kinerja individu sangat penting karena kedua ukuran tersebut mampu melihat aktivitas-aktivitas yang menciptakan benefit yang dilakukan oleh individu. Ukuran finansial memiki obyektifitas yang lebih baik dari ukuran non finansial karena memiliki ukuran yang sifatnya kuantitatif dan pasti. Subyektifitas ukuran non finansial terjadi karena item yang diukur tidak mudah dikuantifikasikan. Sebaliknya ukuran non finansial mampu mengukur aktivitas individu dari banyak dimensi sehingga lebih sesuai dengan aktivitas yang akan diukur.

Otley (1978) menyatakan bahwa ukuran yang digunakan untuk mengukur kinerja individu berpengaruh terhadap perilaku individu. Persepsi fairness individu terhadap ukuran kinerja menjelaskan efek ukuran kinerja terhadap perilaku individu. Keadilan prosedural adalah persepsi fairness individu terhadap semua aspek dari prosedur dan proses yang digunakan oleh superior dalam melakukan evaluasi terhadap kinerja subordinat, mengkomunikasikan feedback dan menentukan reward (Lind dan Tyler, 1988). Pernyataan ini konsisten dengan pendapat Alexander dan Ruderman (1987) bahwa keadilan prosedural mempengaruhi perilaku individu.

Ukuran kinerja non finansial dipersepsikan fair karena ukuran ini mampu mencakup banyak variasi aktivitas individu sehingga banyak dimensi yang dapat dievaluasi dan feedback yang diterima akan lebih relevan bagi individu. Karakteristik ukuran non finansial ini akan membuat individu termotivasi untuk berperilaku yang memberikan benefit bagi organisasinya meski aktivitasnya tidak secara langsung berkaitan dengan profit yang dicapai organisasi. Hal ini berarti 
prosedur dan proses pengukuran kinerja dipersepsikan fair dan memiliki konsekuensi bagi terbentuknya perilaku positif individu.

Goal setting theory menjelaskan bahwa terdapat hubungan antara tujuan dan kinerja seseorang terhadap tugas. Tujuan yang spesifik dan memiliki tingkat kesulitan tertentu menyebabkan kinerja lebih baik daripada tujuan yang mudah (Locke, 1968). Konsep ini dapat digunakan untuk meningkatkan motivasi kerja individu untuk menghasilkan kinerja tertentu.

Tujuan merupakan nilai atau keluaran yang diharapkan akan terjadi yang dapat ditentukan dalam jangka pendek atau jangka panjang (Locke dan Latham, 1991). Hal ini berarti tujuan dibuat untuk dapat berfungsi sebagai standar bagi evaluasi semua aktivitas yang digunakan untuk mencapai tujuan dan kinerja yang dicapai. Goal setting theory menjelaskan karakterisik tujuan yang dapat memotivasi individu, baik motivasi intrinsik maupun ekstrinsik), dalam mencapai tujuannya. Salah satu karakteristik dari goal setting adalah tingkat kesulitan tujuan. Tingkat kesulitan tujuan yang berbeda akan memberikan motivasi yang berbeda bagi individu untuk mencapai kinerja tertentu. Tingkat kesulitan tujuan yang rendah akan membuat individu memandang bahwa tujuan sebagai pencapaian rutin yang mudah dicapai sehingga akan menurunkan motivasi individu untuk berkreativitas dan berkembang kemampuannya. Sedangkan pada tingkat kesulitan tujuan yang lebih tinggi tetapi mungkin untuk capai, individu akan termotivasi untuk berfikir cara pencapaian tujuan tersebut. Proses ini akan menjadi sarana berkembangnya kreatifitas dan kemampuan individu untuk mencapai tujuan tertentu. Hal ini berarti bahwa tingkat kesulitan tujuan tertentu akan membentuk motivasi individu untuk mencapai tujuan dengan lebih baik.

Locke dkk (1981) menyatakan bahwa goal difficulty dan task difficulty merupakan dua istilah yang biasanya dipahami sama sehingga dapat dipertukarkan. Goal difficulty dan task difficulty merupakan dua hal yang berbeda karena tugas merupakan bagian dari pekerjaan yang dicapai. Kesulitan tugas berkaitan dengan kemampuan kognisi dan motivasi indvidu untuk dapat mengerjakan tugas itu sehingga memberikan kinerja tertentu. Bandura (1997) menjelaskan bahwa tingkat kesulitan tugas berpengaruh terhadap keyakinan seseorang untuk dapat menyelesaikan tugas dan kinerjanya. Perspektif lain berpendapat bahwa ketika individu memiliki keyakinan bahwa mereka mampu menyelesaikan tugas tertentu maka tingkat kesulitan tugas akan menjadi tantangan bagi individu untuk menyelesaikannya dengan baik (Wood dan Bandura, 1989).

Empowerment dapat dipahami sebagai praktik organisasi, teknik manajemen, pendelegasian kekuasaan (Tannenbaum), otonomi (Kanter), leadership skills (Burke), teambuilding experiences (Nielsen), intrinsic motivation or self-determination (Deci), effectance motivation or competency (White), sense of control (Lawler), need for power (McClelland), and self- efficacy (Bandura) dalam Hartmann dan Slapnicar (2007).

Empowerment menjadi cara membentuk motivasi subordinat dengan memberikan diskresi kepada subordinat untuk membuat keputusan pekerjaan yang menjadi tanggung jawabnya. Subordinat akan belajar untuk membuat keputusan yang efektif dan bertanggungjawab atas konsekuensi dari keputusan yang diambil. Efek learning terjadi ketika superior memberikan evaluasi atas kinerja subordinat. Thomas dan Velthouse's (1990) beragumentasi bahwa empowerment mengandung pengertian perlunya keleluasaan kepada individu untuk bertindak dan bertanggung jawab atas keputusan yang dibuat. Tiga dimensi empowerment menurut Drake, Wong dan Salter (2007) digunakan dalam penelitian ini. Dimensi impact didefinisikan sebagai keyakinan subordinat bahwa perilakunya akan memiliki konsekuensi terhadap pencapaian tujuan. Dimensi competence merupakan keyakinan individu bahwa dirinya mampu melakukan tugasnya dengan baik. Self 
determination menjelaskan keyakinan individu bahwa dirinya dapat menentukan cara yang paling baik untuk melaksanakan tugasnya.

Sebagian besar riset dan praktik menggunakan ukuran finansial untuk menilai kinerja individu dan memberikan temuan yang tidak konsisten. Kaplan (1984) menyatakan konsep pengukuran kinerja berdasarkan ukuran non keuangan mampu menjelaskan bagaimana dimensi non keuangan dapat memberikan motivasi. McFarlin dan Sweeney (1992) menyatakan bahwa persepsi individu terhadap fairness dari ukuran kinerja berpengaruh terhadap perilaku individu. Ukuran non keuangan yang memiliki karakteristik mengukur kinerja melalui banyak dimensi yang dapat disesuaikan dengan aktivitas individu yang diukur (Lau dan Sholihin, 2005). Sedangkan ukuran keuangan hanya mengukur satu dimensi saja yaitu pencapaian kinerja keuangan dari aktivitas yang dilakukan oleh subordinat. Pada dasarnya tidak semua subordinat memiliki aktivitas yang berkaitan langsung dengan pencapaian profit organisasi, sehingga ketika ukuran yang digunakan adalah ukuran finansial, maka banyak dimensi dari ektivitas mereka yang tidak memperoleh fokus dan umpan balik dari superior untuk perbaikan kinerja mereka.

Target pencapaian subordinat merupakan tujuan yang harus dicapai. Tidak semua target yang menjadi tujuan yang harus dicapai dipersepsikan sebagai tujuan yang mudah untuk dicapai. Tingkat kesulitan tujuan yang dijelaskan oleh goal setting theory merupakan aspek yang dapat memotivasi individu untuk memiliki kinerja yang baik. Tetapi, pada tingkat tertentu kesulitan tujuan akan menjadi aspek yang membentuk demotivasi insdividu. Artinya, persepsi mengenai tingkat kesulitan tujuan yang harus dicapai, akan mempengaruhi persepsi fairness subordinat terhadap sistem penilaian kinerja yang akan digunakan untu mengukur kinerjanya. Hal ini berarti, tingkat kesulitan tujuan akan menjadi variabel kontijen yang akan mempengaruhi efek sistem penilaian kinerja terhadap keadilan prosedural. Berdasarkan argumentasi di atas maka, hipotesis yang diajukan adalah:

\section{H1: Tingkat kesulitan tujuan memoderasi efek sistem penilaian kinerja terhadap keadilan prosedural.}

Hipotesis yang akan dirumuskan dalam riset ini didasarkan pada pendapat Wood dan Bandura (1989) yang menyatakan bahwa tingkat kesulitan tugas merupakan tantangan bagi individu untuk dapat menyelesaikannya dengan baik. Kesulitan tugas menjadi motivasi bagi individu untuk mengembangkan kemampuan kognitifnya. Dilain pihak, tingkat kesulitan tugas yang tinggi akan lebih mudah terjadi kesalahan dibandingkan ketika individu memiliki tingkat kesulitan tugas yang lebih rendah (Bandura dalam Ning Ho, 2010).

Ukuran non finansial merupakan ukuran kinerja yang memungkinkan individu memiliki poin penilaian yang beragam dan tidak hanya didasarkan pada satu dimensi keuangan saja. Secara konsep dijelaskan bahwa ukuran kinerja non finansial mampu digunakan untuk mengukur kinerja subordinat lebih relevan dengan lingkungan dan aktivitas dimana individu bekerja. Hal ini berarti relevansi dari ukuran kinerja non finansial lebih tinggi dibandingkan dengan ukuran kinerja finansial, terlebih pada subordinat yang aktivitasnya tidak berhubungan langsung dengan pencapaian profit organisasi.

Tingkat kesulitan tugas akan mempengaruhi seberapa baik subordinat mampu melakukan tugasnya dengan baik dan menghasilkan kinerja yang baik, sedangkan sistem penilaian kinerja memberikan informasi bagaimana kinerja subordinat akan diukur. Hal ini berarti persepsi fairness ukuran kinerja tidak saja tergantung dari sistem penilaian kinerja tetapi juga karakteristik kesulitan tugas yang dilakukan oleh subordinat. Tingkat kesulitan tugas dapat mempengaruhi 
persepsi fairness subordinat terhadap sistem penilaian kinerja yang digunakan untuk mengukur kinerjanya. Berdasarkan penjelasan di atas, maka hipotesis yang diusulkan dalam penelitian ini adalah:

\section{H2: Tingkat kesulitan tugas memoderasi efek sistem penilaian kinerja terhadap keadilan prosedural}

Keadilan prosedural menunujukkan persepsi individu mengenai fairness dari ukuran kinerja yang digunakan untuk mengukur kinerjanya. Temuan Thibaut dan Walker (1975) menyatakan bahwa persepsi fairness individu terhadap prosedur pembuatan keputusan yang digunakan dalam organisasi berpengaruh terhadap sikap dan perilaku individu. Prosedur yang fair memungkinkan individu untuk berinteraksi yang secara sosial dan psikologis sehingga memiliki kinerja yang baik (Lind dan Tyler, 1988). Hal ini berarti persepsi yang fair atas prosedur dan proses pengukuran kinerja akan memotivasi individu untuk berperilaku positif.

Empowerment dapat dipahami sebagai diskresi yang diberikan oleh superior kepada subordinat untuk membuat keputusan atas semua pekerjaan yang menjadi tanggung jawabnya. Dimesi pengukuran empowerment menunjukkan bagaimana disekresi yang diberikan kepada subordinat dapat memotivasi untuk meningkatkan kinerjanya. Impact, competence dan self determination menjelaskan bahwa diskresi yang diberikan dapat membuat subordinat memahami pengaruh keputusan, kemampuan dan strategi yang dibuat terhadap pencapaian kinerja bagian yang menjadi tanggung jawabnya. Thomas dan Velthouse's (1990) beragumentasi bahwa empowerment mengandung pengertian perlunya keleluasaan kepada individu untuk bertindak dan bertanggung jawab atas keputusan yang dibuat.

Ketika individu mempunyai persepsi yang fair terhadap ukuran kinerja yang digunakan untuk mengevalusi kinerjanya maka kondisi ini akan mempengaruhi perilaku individu yang memiliki diskresi untuk membuat keputusan yang memberikan benefit bagi organisasi. Brewer dan Kramer (1986) menunjukkan bahwa individu yang memberikan evaluasi positif terhadap perlakuan dan penghargaan atasan atas pekerjaan yang telah dilakukan, sehingga bawahan cenderung memiliki perilaku kooperatif yang memberikan benefit bagi organisasi. Berdasarkan penjelasan di atas, hipotesis yang diusulkan adalah:

\section{H3: Empowerment memediasi pengaruh keadilan prosedural terhadap kinerja.}

Penelitian ini menggunakan metoda eksperimen dan menggunakan mahasiswa Fakultas Ekonomi dan Bisnis Unika Soegijapranata Semarang sebagai subyek riset. Data yang diolah dalam penelitan ini adalah data dari subyek yang terlibat dan lolos cek manipulasi.

Penelitian ini memiliki desain eksperimen $2 \times 2 \times 2$ (ukuran kinerja, kesulitan tujuan dan kesulitan tugas) between subject. Manipulasi dilakukan pada variabel pengukuran kinerja melalui tugas pembuatan kotak dan ukuran kinerja dari tugas, sedangkan variabel kesulitan tujuan dan kesulitan tugas hanya diukur. Cek manipulasi dilakukan untuk tritmen penggunaan ukuran kinerja finansial dan non finansial.

Pengukuran kinerja dalam penelitian ini didefinisikan sebagai pengukuran kinerja subordinat dengan ukuran keuangan dan non keuangan. Pengukuran kinerja dikur dengan memberikan tugas pembuatan kotak dari karton yang tersedia. Subyek dengan ukuran keuangan adalah subyek yang kinerjanya dihitung dari banyaknya jumlah kotak baik yang dihasilkan. Sedangkan untuk ukuran non keuangan, subyek diukur berdasarkan banyaknya jumlah bentuk hiasan yang ditempel pada sisi-sisi kubus. Semakin banyak variasi bentuk hiasan pada kubus, semakin baik kinerja subyek. 
Keadilan prosedural didefinisikan sebagai persepsi subordinat mengenai fairness dari ukuran kinerja yang digunakan untuk mengukur kinerja subordinat. Keadilan prosedural ini diukur dengan instrumen McFarlin dan Sweeney (1992) dengan skala likert 1 sampai 5. Semakin tinggi skor maka semakin fair persepsi subordinat terhadap ukuran kinerja yang digunakan untuk mengukur kinerjanya.

Empowerment didefinisikan dengan tiga dimensi yang akan digunakan dalam pengukuran empowerment

a) Impact didefinisikan sebagai persepsi subordinat mengenai keyakinan bahwa perilakunya dalam membuat kotak mempunyai dampak terhadap kinerja.

b) Competence didefinisikan sebagai persepsi subordinat mengenai keyakinan bahwa dirinya mampu membuat kotak dengan baik.

c) Self determination didefinsikan sebagai persepsi subordinat tentang keyakinan bahwa dirinya dapat memilih cara yang baik untuk dapat membuat kotak dengan baik. Pengukuran empowerment menggunakan instrumen Drake, Wong dan Salter (2007).

Kinerja didefinisikan sebagai jumlah kotak yang selesai dibuat (keuangan) dan jumlah variasi bentuk hiasan dari kotak yang selesai dibuat. Penelitian ini menggunakan Anova dan SEM-PLS untuk menguji hipotesis yang telah dirumuskan. Pengujian validitas dan reliabilitas instrumen dilakukan dengan SEM-PLS dan uji validitas desain digunakan ANOVA.

HASIL DAN PEMBAHASAN

Tabel 1. Analisis Statistik Deskriptif

\begin{tabular}{|c|c|c|c|c|c|}
\hline Keterangan & \multicolumn{2}{|c|}{$\begin{array}{l}\text { Penilain Kinerja } \\
\text { Non Finansial }\end{array}$} & \multicolumn{2}{|c|}{$\begin{array}{l}\text { Penilain Kinerja } \\
\text { Finansial }\end{array}$} & TOTAL \\
\hline Subjek (n) & \multicolumn{2}{|c|}{57} & \multicolumn{2}{|c|}{26} & $\begin{array}{l}8 \\
3\end{array}$ \\
\hline $\begin{array}{l}\text { Tingkat Kesulitan } \\
\text { Tujuan }\end{array}$ & \multicolumn{2}{|c|}{$\begin{array}{l}\text { Tinggi: } 24 \\
\text { Rendah: } 23\end{array}$} & \multicolumn{2}{|l|}{$\begin{array}{c}\text { Tinggi:16 } \\
\text { Rendah: } 20\end{array}$} & $\begin{array}{l}8 \\
3\end{array}$ \\
\hline $\begin{array}{c}\text { Tingkat Kesulitan } \\
\text { Tugas }\end{array}$ & \multicolumn{2}{|c|}{$\begin{array}{c}\text { Tinggi: } 18 \\
\text { Rendah: } 29\end{array}$} & \multicolumn{2}{|c|}{$\begin{array}{c}\text { Tinggi: } 16 \\
\text { Rendah : } 20\end{array}$} & $\begin{array}{l}8 \\
3 \\
\end{array}$ \\
\hline & $\begin{array}{c}\text { Tingkat } \\
\text { Kesulitan } \\
\text { Tujuan Tinggi }\end{array}$ & $\begin{array}{c}\text { Tingkat } \\
\text { Kesulitan } \\
\text { Tujuan Rendah }\end{array}$ & $\begin{array}{l}\text { Tingkat } \\
\text { Kesulitan } \\
\text { Tujuan Tinggi }\end{array}$ & $\begin{array}{c}\text { Tingkat } \\
\text { Kesulitan } \\
\text { Tujuan Rendah }\end{array}$ & \\
\hline Kinerja (mean) & 2,46 & 2,65 & 4,50 & 4,00 & \\
\hline Impact & 5,17 & 5,78 & 5,81 & 5,20 & \\
\hline Competence & 5,25 & 5,52 & 5,77 & 5,23 & \\
\hline Self Detemination & 5,83 & 5,57 & 5,06 & 5,00 & \\
\hline \multirow[t]{2}{*}{ Keadilan Prosedural } & 5,5 & 5,91 & 5,38 & 5,35 & \\
\hline & $\begin{array}{c}\text { Tingkat } \\
\text { Kesulitan } \\
\text { Tugas Tinggi }\end{array}$ & $\begin{array}{c}\text { Tingkat } \\
\text { Kesulitan Tugas } \\
\text { Rendah }\end{array}$ & $\begin{array}{c}\text { Tingkat } \\
\text { Kesulitan Tugas } \\
\text { Tinggi }\end{array}$ & $\begin{array}{c}\text { Tingkat } \\
\text { Kesulitan Tugas } \\
\text { Rendah }\end{array}$ & \\
\hline Kinerja & 2,39 & 2,67 & 3,75 & 4,6 & \\
\hline Impact & 5,50 & 5,45 & 5,19 & 5,70 & \\
\hline Competence & 5,22 & 5,48 & 5,05 & 5,08 & \\
\hline Self Determination & 5,67 & 5,72 & 4,81 & 5,20 & \\
\hline KP & 5,61 & 5.76 & 5,18 & 5,50 & \\
\hline
\end{tabular}

Sumber: Data primer yang diolah (2014) 
Penelitian ini menggunakan analisis deskriptif untuk menjelaskan gambaran umum secara menyeluruh terkait dengan subjek dalam penelitian ini, seperti terlihat pada Tabel 1.

Tabel 1 memberikan penjelasan bahwa eksperimen ini diikuti oleh 83 subjek, 57 subjek ditritmen dengan sistem penilaian kinerja non finansial dan 26 dengan sistem penilaian kinerja finansial. Masing-masing dari tiap sistem penilaian kinerja diberikan tritmen mengenai tingkat kesulitan tujuan dan tingkat kesulitan tugas dengan jumlah berturut-turut 47 dan 36 subjek. Rerata keadilan prosedural untuk tiap sel menunjukkan nilai rerata yang tinggi dengan rerata pada skala 5 dari 7 skala pengukuran keadilan prosedural. Aspek empowerment menunjukkan nilai rerata tinggi pada skala 5 dari 7 skala pengukuran impact, competence dan self determination. Kinerja menunjukkan rerata yang berbeda untuk subjek dengan sistem penilai kinerja finansial dan non finansial.

\section{Pengujian Validitas dan Reliabilitas Instrumen}

Pengukuran validitas dan reliabilitas dilakukan dengan model pengukuran instrumen tiap konstruk yang digunakan dalam riset. Tabel 2 merupakan hasil pengujian validitas dan reliabilitas instrumen dari konstruk riset ini:

Tabel 2. Hasil Pengujian Validitas dan Reliabilitas

\begin{tabular}{|c|c|c|c|c|c|}
\hline & $\mathrm{KP}$ & Impact & Competence & $\begin{array}{c}\text { Self } \\
\text { Determination }\end{array}$ & Kinerja \\
\hline AVE & 0,574 & 0,707 & 0,647 & 0,720 & 1 \\
\hline Communality & 0,574 & 0,707 & 0,648 & 0,719 & 1 \\
\hline $\begin{array}{l}\text { Loading } \\
\text { Factor }\end{array}$ & $\begin{array}{l}\text { KP1: } \\
0,718 \\
\text { KP2: } \\
0,819 \\
\text { KP3: } \\
0,793 \\
\text { KP5: } \\
0,718\end{array}$ & $\begin{array}{l}\text { I1: } 0,821 \\
\text { I2: } 0,863 \\
\text { I3: } 0,815\end{array}$ & $\begin{array}{l}\text { C1: } 0,837 \\
\text { C2: } 0,807 \\
\text { C3: } 0,875\end{array}$ & $\begin{array}{l}\text { SDT1: } 0,730 \\
\text { SDT2: } 0,950\end{array}$ & 1 \\
\hline
\end{tabular}

\begin{tabular}{cccccc}
\hline $\begin{array}{c}\text { Correlation } \\
\begin{array}{c}\text { Vs Square Of } \\
\text { AVE }\end{array}\end{array}$ & 0,758 & 0,841 & 0,805 & 0,848 & 1 \\
\hline $\begin{array}{c}\text { Cronbachs } \\
\text { Alpha }\end{array}$ & 0,764 & 0,796 & 0,740 & 0,650 & 1 \\
\hline $\begin{array}{c}\text { Composite } \\
\text { Reliability }\end{array}$ & 0,574 & 0,879 & 0,845 & 0,834 & 1 \\
\hline
\end{tabular}

Sumber : Data primer yang diolah (2014)

Tabel 2 menunjukkan bahwa konstruk berikut instrumen dari Keadilan Prosedural (KP), Impact, Competence dan Self Determination valid. Hal ini ditunjukkan oleh nilai AVE dan Communality yang lebih besar dari 0,5. Nilai loading factor lebih besar dari 0,7 dan nilai akar AVE yang lebih besar dari korelasi antara variabel laten menunjukkan bahwa instrumen yang digunakan dalam pengukuran konstruk dalam riset ini valid. Pengujian reliabilitas menunjukkan bahwa instrumen yang digunakan dalam pengukuran konstruk reliabel. Hal ini ditunjukkan oleh nilai cronbach alpha dan composite reliability lebih besar dari 0,6. 


\section{Pengujian Hipotesis dan Pembahasan}

Hipotesis pertama dan kedua menguji efek interaksi penilaian kinerja dan tingkat kesulitan tugas terhadap kinerja dan efek interaksi penilaian kineerja dan tingkat kesulitan tugas terhadap kinerja. Tabel 3 adalah hasil pengujian interaksi hipotesis satu dan hipotesis dua:

Tabel 3. Hasil Pengujian Interaksi Hipotesis 1 dan Hipotesis 2

\begin{tabular}{ll}
\hline Interaksi & Sig \\
\hline Penilaian Kinerja * Kesulitan Tujuan & 0,312 \\
Penilaian Kinerja * Kesulitan Tugas & 0,708 \\
\hline
\end{tabular}

Sumber : Data primer yang diolah (2014)

Hasil pengujian interaksi antara penilain kinerja dan kesulitan tujuan menunjukkan nilai tstatistik sebesar 0,312 , sehingga tidak terbukti adanya interaksi antara penilain kinerja dan kesulitan tujuan terhadap keadilan prosedural. Interaksi penilaian kinerja dan kesulitan tugas tidak memiliki efek terhadap keadilan prosedural dengan nilai $t$ statistik 0,708 .

Pengujian di atas menjelaskan bahwa tingkat kesulitan tujuan dan tingkat kesulitan tugas bukan merupakan variabel yang memoderasi efek penilaian kinerja terhadap persepsi fairness bawahan mengenai ukuran kinerja yang digunakan untuk mengevaluasi pekejaannya. Rerata dari persepsi fairness bawahan mengenai ukuran kinerja tidak berbeda signifikan secara statistik. Hasil ini mendukung temuan Argumentasi penolakan hipotesis 1 dan hipotesis 2 dapat dijelaskan dalam dua sudut pandang desain eksperimen dan teori.

Cek manipulasi yang digunakan untuk memberikan keyakinan bahwa subjek berada dalam kondisi tingkat kesulitan tujuan dan tingkat kesulitan tugas tertentu yang dikondisikan oleh peneliti. Cek manipulasi telah menunjukkan bahwa subjek pada tritmen tingkat kesulitan tujuan dan tingkat kesulitan tugas memberikan hasil yang sama dengan kondisi tritmen yang diinginkan peneliti. Tetapi, rerata dari keadilan prosedural dalam Tabel 3 menunjukkan persepsi fairness bawahan terhadap ukuran kinerja yang digunakan untuk mengevaluasi kinerja di 4 sel memiliki nilai hampir sama dan tidak berbeda secara statistik. Hal ini didukung oleh hasil pengujian dalam lampiran 6 yang menunjukkan tidak adanya perbedaan signifikan keadilan prosedural pada sistem penilaian kinerja keuangan dan non keuangan.

Tidak terdapat perbedaan keadilan prosedural terjadi karena subjek disemua sel mempunyai persepsi bahwa cara dan ukuran penilaian kinerja yang dialami dalam eksperimen adalah fair. Instrumen yang dapat menunjukkan ekuitabilitas dalam hal reward dari pekerjaan yang dilakukan ternyata tidak valid untuk digunakan dalam pengukuran keadilan prosedural (dari sisi instrumental), sehingga perbedaan fairness dari sisi skema reward tidak dapat diukur. Hal ini tidak memenuhi aspek persepsi fairness terhadap proses penilaian kinerja mengenai penentuan reward bagi subordinat yang dijelaskan oleh Lind dan Tyler (1988) dan McFarlin dan Sweeney (1992).

Hipotesis ketiga dalam riset ini menyatakan bahwa aspek empowerment, yaitu impact, competence dan self determination memediasi efek keadilan prosedural terhadap kinerja individu. Tabel 4 menjelaskan hasil pengujian hipotesis.

Hasil pengujian mediasi menunjukkan bahwa impact memediasi efek keadilan prosedural terhadap kinerja. Efek tidak langsung dari keadilan prosedural terhadap impact menunjukkan nilai t statistik lebih dari 2,952 dengan alpha $5 \%$ dan efek impact terhadap kinerja nila t statistik 1,990 dengan alpha $5 \%$. Sedangkan efek langsung keadilan prosedural terhadap kinerja menunjukkan 
nilai t statistik sebesasar 1,024 dengan alpha 5\%. Hal ini berarti terdapat efek tidak langsung keadilan prosedural terhadap kinerja melalui impact.

Tabel 4. Hasil Pengujian Hipotesis 3

\begin{tabular}{ccc}
\hline & $\begin{array}{c}\text { Original Sample } \\
(\mathrm{O})\end{array}$ & $\begin{array}{c}\text { T Statistics } \\
(|\mathrm{O} / \mathrm{STERR}|)\end{array}$ \\
\hline $\mathrm{COM}->\mathrm{KI}$ & 0,200914 & 1,899369 \\
IM $>$ KI & 0,213409 & 1,989719 \\
KP $>$ COM & 0,275921 & 2,826332 \\
KP $>$ IM & 0,30261 & 2,952394 \\
KP -> KI & 0,060415 & 1,024009 \\
KP -> SDT & 0,229134 & 2,016032 \\
SDT -> KI & $-0,260112$ & 3,411782 \\
\hline
\end{tabular}

Sumber : Data primer yang diolah (2014)

Oleh karena itu dapat disimpulkan bahwa impact memediasi efek keadilan prosedural terhadap kinerja. Efek mediasi ini disebut full mediation karena efek langsung keadilan prosedural terhadap kinerja tidak signifikan ketika impact menjadi mediasi dalam hubungan tersebut. Aspek kedua dari empowerment, competence menunjukkan adanya efek keadilan prosedural terhadap competence dengan nilai t statistik sebesar 2,828 pada alpha $5 \%$ dan competence memiliki efek signifikan terhadap kinerja pada alpha $10 \%$ dengan nilai t statistik sebesar 1,900. Sedangkan efek keadilan prosedural terhadap kinerja yang menunjukkan efek langsung memiliki nilai t statistik sebesasar 1,024 dengan alpha 5\%. Artinya, ditemukan adanya efek mediasi competence pada efek keadilan prosedural terhadap kinerja dan efek mediasi ini dapat dikategorikan sebagai efek full mediation. Berdasarkan Tabel 4, self determination memediasi efek keadilan prosedural terhadap kinerja. Hubungan tidak langsung menunjukkan adanya efek keadilan prosedural terhadap self determination dengan nilai t statistik sebesar 2,016 pada alpha $5 \%$ dan efek self determination terhadap kinerja dengan nilai t statistik sebesar 3,411. Efek langsung keadilan prosedural terhadap kinerja yang signifikan menunjukkan efek mediasi self determination merupakan efek full mediation.

Temuan adanya efek mediasi aspek empowerment, yaitu impact, competence dan self determination, pada pengaruh keadilan prosedural terhadap kinerja menjelaskan proses perilaku terbentuk. Hopwood dalam Lau dan Sholihin (2005) dan Lind danTyler (1988) menjelaskan bahwa keadilan prosedural memiliki efek terhadap sikap individu dalam organisasi. Hal ini dapat dilihat dari temuan riset ini bahwa persepsi yang fair terhadap ukuran penilaian kinerja dapat membentuk motivasi subordinat yang terlihat dari adanya efek keadilan prosedural masing-masing terhadap impact, competence dan self determination.

Persepsi yang fair terhadap ukuran penilaian kinerja memiliki efek terhadap terbentuknya impact, yaitu keyakinan subordiant bahwa dirinya mempunyai pengaruh terhadap kinerja organisasi. Ketika keyakinan ini terbentuk, maka kinerja subordinat akan meningkat. Hubungan positif keadilan prosedural terhadap impact dan impact terhadap kinerja mejelaskan bagaimana persepsi yang semakin fair mengenai ukuran kinerja dapat meningkatkan kinerja subordinat. Ukuran kinerja yang dipersepsikan fair oleh subordinat akan memberikan motivasi untuk bekerja dengan baik ketika subordinat memiliki keyakinan bahwa kinerja yang baik sangat tergantung dari pekerjaan yang dilakukannya. 
Competence menunjukkan keyakinan subodinat bahwa dirinya memiliki kemampuan untuk dapat melaksanakan tugas dengan baik. Hasil pengujian mediasi menunjukkan bahwa competence memediasi efek keadilan prosedural terhadap kinerja. Hal ini berarti persepsi yang fair terhadap ukuran kinerja akan memotivasi subordinat merasa yakin akan kemampuannya untuk melakukan tugasnya dengan baik, sehingga kinerja meningkat. Hubungan positif dari efek pengujian efek mediasi menunjukkan bahwa semakin fair persepsi subordinat terhadap ukuran kinerja, semakin meningkatkan keyakinan subodinat untuk mampu melaksanakan tugasnya dengan baik dan kinerja akan meningkat. Persepsi yang fair terhadap ukuran kinerja memberikan keyakinan bahwa proses penilaian kinerja akan dilakukan dengan fair bagi subordinat untuk tugas yang telah mereka lakukan. Kondisi ini akan membuat keyakinan subordinat untuk dapat melaksanakan tugasnya meningkat dan berkinerja lebih baik. Temuan ini mendukung hasil riset Lau dan Sholihin (2005) yang menyatakan pentingnya persepsi yang fair terhadap ukuran untuk menjelaskan perilaku subordinat. Hasil pengujian mediasi dalam Tabel 4 menunjukkan bahwa self determination memediasi efek keadilan prosedural terhadap kinerja subordinat. Artinya, fairness dari ukuran kinerja yang digunakan untuk menilai kinerja subordinat memiliki pengaruh terhadap keyakinan subordinat dalam menggunakan cara yang paling baik untuk menyelesaikan tugasnya. Keadilan prosedural akan mendorong subordinat untuk berfikir mengenai efisiensi dan efektifitas yang harus dipertimbangkan dalam melakukan tugasnya.

Hal menarik yang ditemukan dalam riset ini adalah adanya efek mediasi yang signifikan tetapi memiliki arah yang menunjukkan adanya hubungan negatif antara self determination dan kinerja. Temuan ini mengindikasikan bahwa semakin tinggi keyakinan subordinat bahwa mereka boleh memilih cara yang baik untuk menyelesaikan tugasnya, maka semakin rendah kinerjanya. Artinya, kebebasan untuk memilih cara menyelesaikan tugas yang diyakini suboedinat dalam riset ini tidak meningkatkan kinerja subordinat.

Temuan ini dapat dijelaskan melalui desain eksperimen yang digunakan dalam riset ini. Tugas yang diberikan dalam eksperimen ini adalah tugas yang dapat dilakukan oleh siapapun, yaitu membentuk potongan kertas yang telah dibentuk menjadi sebuah kotak (kubus). Meski telah ada sesi latihan dan dalam cek manipulasi subjek memahami kriteria kubus yang akan dinilai sebagai kinerja, tetapi dalam pelaksanaannya cara kerja yang tidak seragam diantara subjek membuat subjek dapat melakukan kesalahan sehingga kubus yang telah dibuat tidak dapat dikategorikan sebagai kinerja. Argumentasi ini didasarkan pada kondisi saat eksperimen dilakukan.

\section{PENUTUP}

Pengujian hipotesis dalam riset ini memberikan beberapa simpulan. Pertama, tingkat kesulitan tujuan dan tingkat kesulitan tugas tidak memoderasi efek sistem penilaian kinerja terhadap keadilan prosedural. Aspek goal setting theory yang diwakili oleh kesulitan tujuan dan kesulitan tugas yang diprediksi menjadi variabel kontijen untuk menjelaskan efek sistem penilaian kinerja terhadap keadilan prosedural tidak terbukti. Tingkat kesulitan tujuan dan tingkat kesulitan tugas diprediksi menjadi variabel independen yang berpengaruh terhadap keadilan prosedural. Kedua, sspek empowerment, yaitu impact, competence dan self determination, memediasi efek keadilan prosedural terhadap kinerja. Temuan riset ini menjelaskan bahwa persepsi fair terhadap ukuran penilaian kinerja dapat membentuk motivasi subordinat yang dijelaskan oleh aspek empowerment dan mempengaruhi kinerja. Impact dan competence memiliki efek mediasi positif yang meningkatkan kinerja subordinat, sedangakan self determination justru memiliki efek negatif terhadap kinerja. 
Riset ini mempunyai beberapa keterbatasan yang dapat menjadi materi perbaikan dan pengembangan riset selanjutnya. Desain eksperimen riset ini mempunyai kelemahan karena pekerjaan/tugas untuk penilaian kinerja berdasarkan finansial dan non finansial tidak mampu menangkap adanya perbedaan keadilan prosedural seperti yang diprediksikan dalam konsep yang dikembangkan dalam riset ini. Perbedaan tugas sangat kecil sehingga tidak dapat dipahami sebagai tugas dengan pengukuran kinerja yang berbeda. Pengalaman riset ini memberikan peluang untuk mengembangkan model desain tugas dalam eksperimen yang dapat mengeskpresikan perbedaan penilaian kinerja. Kelemahan kedua dari desain riset ini adalah ketidakcermatan subjek untuk menghasilkan kubus yang dapat diperhitungkan sebagai kinerja justru dapat menurunkan kinerja. Hal yang harus diperbaiki adalah perlu sesi latihan yang cukup agar subjek dapat memahami cara menghasilkan kubus yang baik dan selanjutnya dapat memilih sendiri cara yang tepat untuk meningkatkan kinerjanya.

\section{REFERENSI}

Alexander, S \& Ruderman, A. (1987). The role of procedural and distributive justice in organizational behavior. Social justice research, vol. 1, 177-198.

Brewer, M.B, \& Kramer, R.M. (1986). Choice behavior in social dillemas: Effects of social identity, group size and decision faming. Journal of personality and social psychology, 50.

Coote. Leonard V, Evan Price \& Anna Lena. (2004). An investigation into the antecedents of goal congruence in retail-service setting. Journal of service marketing, vol.18.

Drake, Andrea R, Jeffrey Wong \& Stephen B. Salter. (2007). Empowerment, motivation and performance: Examining the impact of feedback and incentives on nonmanagement employees. Behavioral research in accounting, 19: 71-89.

Fisher, Joseph G, Sean A. Peffer \& Geoffrey B. Sprinkle. (2003). Budget-based contracts , budgt levels and group performance. Journal of management accounting research, vol.15.

Hopwood, A.G. (1972). An empirical study of the role of accounting data in performance evaluation. Empirical research in accounting: Selected studies. Journal of accounting research 10, 156182.

Hoque, Z.,Mia, L., \& Alam, M. (2001). Market competition, computer-aided manufacturing and use of multiple performance measures: An Empirical Study. The british accounting review, vol. 33

Kaplan, R.S. (1984). The evolution of management accounting. The accounting review, 390-418

Kaplan, R.S.,Atkinson,A.A.,(1998). Third ed. Advanced Management Accounting, 3. Prentice-Hall, USA.

Kelly, Khim; Vance, Thomas; Webb, Allan. (2010). The interactive effects of subyectivity and goal difficulty on performance: An experimental study. University of Waterloo.

Kruger, Dunning (1999). Unskilled and unware of it: how difficulties in recognizing one's own incompetence lead to inflated self- assessment. Journal of personalitiy and social psychology, vol 77(6), 1121-1134.

Lau, C.M., Lim, E.W. (2002). The effects of procedural justice and evaluative styles on the relationship between budgetary participation and performance. Advances in accounting 19, 139-1.

Lau, Chong M., Sholihin, Mahfud. (2005). Financial and nonfinancial performance measures: How do they affect job satisfaction?. The bristish accounting review, 37, 389-413.

Lind, E. A. \& Tyler, T.R. (1988). The social psychology of procedural justice, Plenum Press NY. 
Locke, E.A., Latham, G.P. (1991). A theory of goal setting and task performance. Prentice Hall, Englewood Cliffs, New Jersey.

Locke, E.A., Shaw, K.N., Saari, L.M., Latham, G.P. (1981). Goal setting and task performance: 19691980". Pschological bulletin, 90, p.125-152.

McFarlin, D.B., Sweeney, P. D. (1992). Distributive and procedural justice as perdictors of satisfaction with personal and organizational outcomes. Academy of management journal 35, 626-637

Ning Ho, Hsin. (2010). The relationship between levels of expertis, task difficulty, perceived selfefficacy and mental effort investment in task performance. Disertasi.

Otley, D.T.,(1978). Budget use and managerial performance. Journal of accounting research, vol 16, 12-148.

Tan, Sharon L.C., Lau, Chong M. (2012). The impact of performance measures on employee fairness perceptions, job satisfaction and organizational commitment, vol. 10(2).

Thibaut, J., Walker, L. (1975). Procedural justice: A psychological analysis. Lawrence erlbaum associates, Hillside N.J.

Thomas, K.W. \& Velthouse's, B.A. (1990). Cognitive elements of empowerment. Academy of management review, 15: 666-681.

Wood, R. E. \& Bandura, A. (1989a). Social cognitive theory of organizational. Academy of Management Review. vol 14(3), 361-384. 